WSRC-MS-96-0338

CONF-970321--9

\title{
Transportable Vitrification System Pilot Demonstration with Surrogate Oak Ridge WETF Sludge
}

by

M. E. Smith

Westinghouse Savannah River Company

Savannah River Site

Aiken, South Carolina 29808

R. P. Singer

S. R. Young

J. R. Zamecnik

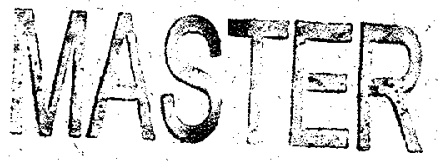

A document prepared for AMERICAN INSTITUTE OF CHEMICAL ENGINEERS SPRING 1997 NATIONAL MEETING at Houston, TX, USA from 3/10/97 - 3/13/97.

DOE Contract No. DE-AC09-89SR18035

This paper was prepared in connection with work done under the above contract number with the $U$. $S$. Department of Energy. By acceptance of this paper, the publisher and/or recipient acknowledges the U.S. Government's right to retain a nonexclusive, royalty-free license in and to any copyright covering this paper, along with the right to reproduce and to authorize others to reproduce all or part of the copyrighted paper. 


\section{DISCLAMMER}

This report was prepared as an account of work sponsored by an agency of the United States Government. Neither the United States Government nor any agency thereof, nor any of their employees, makes any warranty, express or implied, or assumes any legal liability or responsibility for the accuracy, completeness, or usefulness of any information, apparatus, product, or process disclosed, or represents that its use would not infringe privately owned rights. Reference herein to any specific commercial product, process, or service by trade name, trademark, manufacturer, or otherwise does not necessarily constitute or imply its endorsement, recommendation, or favoring by the United States Government or any agency thereof. The views and opinions of authors expressed herein do not necessarily state or reflect those of the United States Govemment or any agency thereof.

This report has been reproduced directly from the best available copy.

Available to DOE and DOE contractors from the Office of Scientific and Technical Information, P.O. Box 62, Oak Ridge, TN 37831; prices available from (615) 576-8401.

Available to the public from the National Technical-Information Service, U.S. Department of Commerce, 5285 Port Royal Road, Springfield, VA 22161. 


\section{DISCLAMMER}

Portions of this document may be illegible in electronic image products. Images are produced from the best available original document. 
WSRC-MS-96-0338

Keywords: Glass, Melter, TVS, LLMW, LLW

\section{TRANSPORTABLE VITRIFICATION SYSTEM PILOT DEMONSTRATION WITH SURROGATE OAK RIDGE WETF SLUDGE (U)}

Michael E. Smith**, Rand P. Singer, Steve R. Young, and Jack R. Zamecnik

Westinghouse Savannah River Company

Savannah River Technology Center

Building 773-23A

Aiken, SC 29808

803-557-7295 (Phone)**

803-557-7210 (FAX)**

A paper proposed for a presentation and abstract publication in the Proceedings of the American Institute of Chemical Engineers Spring 1997 National Meeting, Houston, TX, March 10-March 13, 1997

This paper was prepared in connection with work done under Contract No. DE-AC09-89SR18035 with the Department of Energy. By acceptance of this paper, the publisher and /or recipient acknowledges the U.S Government's right to retain a nonexclusive, royalty-free license in and to any copyright covering this paper, along with the right to reproduce and to authorize others to reproduce all or part of the copyrighted paper. 


\title{
TRANSPORTABLE VITRIFICATION SYSTEM PILOT DEMONSTRATION WITH SURROGATE OAK RIDGE WETF SLUDGE (U)
}

Michael E. Smith, Rand P. Singer, Steve R. Young, and Jack R. Zamecnik

Westinghouse Savannah River Company

Savannah River Technology Center

Building 773-23A

Aiken, SC 29808

\begin{abstract}
Surrogate Oak Ridge Reservation West End Treatment Facility (WETF) sludge was vitrified in a pilot-scale EnVitCo melter at the Clemson University Environmental Systems Engineering Department (ESED) Vitrification Facility. Although much smaller than the Transportable Vitrification System (TVS) melter, this melter is similar in design to the one in the TVS. The TVS was built by EnVitCo for the Savannah River Technology Center (SRTC) for the treatment of low level and mixed wastes. A total of three tests were done by ESED personnel with guidance from SRTC TVS personnel. This work was funded by the Department of Energy Office of Technology Development. The purpose of these tests was to determine what problems might occur during the vitrification of WETF sludge feed in the TVS. The demonstration was successfully completed and the glasses produced passed the TCLP tests for all the hazardous waste components $(\mathrm{Ba}, \mathrm{Cd}, \mathrm{Cr}, \mathrm{Pb}$, and $\mathrm{Ni})$. An overview of these tests and experimental results on glass container testing, glass pouring, glass product characterization, electrode and refractory wear, and offgas composition and particulate measurements will be given.
\end{abstract}

\section{INTRODUCTION}

The Transportable Vitrification System (TVS) has been shipped to the Oak Ridge Reservation (ORR) in FY96 to demonstrate treatment of several low level mixed waste streams. Oak Ridge West End Treatment Facility (WETF) sludge is one of the first waste streams targeted for treatment by the TVS. In support of the TVS program, three tests using surrogate Oak Ridge WETF sludge were conducted at the Clemson University Environmental Systems Engineering Department Vitrification Facility from April to June 1995. A pilot scale TVS melter (EnVitCo EV-16) was used for these tests.

The main objective of these tests was to determine what problems might occur during the vitrification of WETF sludge feed in the TVS. These problems could include low melt rates, devitrification, excessive refractory wear, and pouring difficulties. A secondary objective of these tests was to give SRTC TVS personnel operational experience on a TVS type melter prior to the initial TVS checkout.

\section{EV-16 MELTER SYSTEM DESCRIPTION}

The EV-16 melter is a ceramic-lined, joule heated, cold top melter. The melt surface is square and is approximately 15 inches on each side. Heating is controlled by four below glass molybdenum electrodes, with one located on each of the four sides of the melter. A total of $70 \mathrm{~kW}$ can be delivered to the melter via these electrodes. The glass containment refractory installed was Findlay Flux. Glass pouring occurs through a molybdenum tube located in the bottom of the melter. Pour rates can be controlled by a water cooled probe that inserts into the tube. The melter has a complete offgas system, but it is not prototypic of 
the TVS off-gas system. Ports are located throughout the system for offgas sampling by analyzers or by EPA methods.

\section{TEST SUMMARY}

Three tests were run using surrogate WETF sludge. The ORR WETF process consists of neutralization and heavy metal precipitation with lime, biodenitrification, and uranium copreciptation using ferric sulfate and flocculating polymer. A high percentage of the sludge is therefore calcium carbonate and biomass generated from the biological destruction of nitrate ions. Table I shows the targeted WETF baseline surrogate composition as elemental and anion analyses and also on an oxide-only basis. Cerium was used as a surrogate for uranium. The hazardous wastes in WETF sludge regulated by the Resource Conservation and Recovery Act (RCRA) are also indicated. The first test (OR1-2) used a baseline sludge but no biomass was added. The second test (OR1-3) used the baseline surrogate composition, except the metals were added at ten times their nominal concentrations, except for $\mathrm{Ni}$ which was added at the normal level. The third test (OR1-4) used the baseline surrogate composition.

Table I. Nominal WETF Target Surrogate Composition

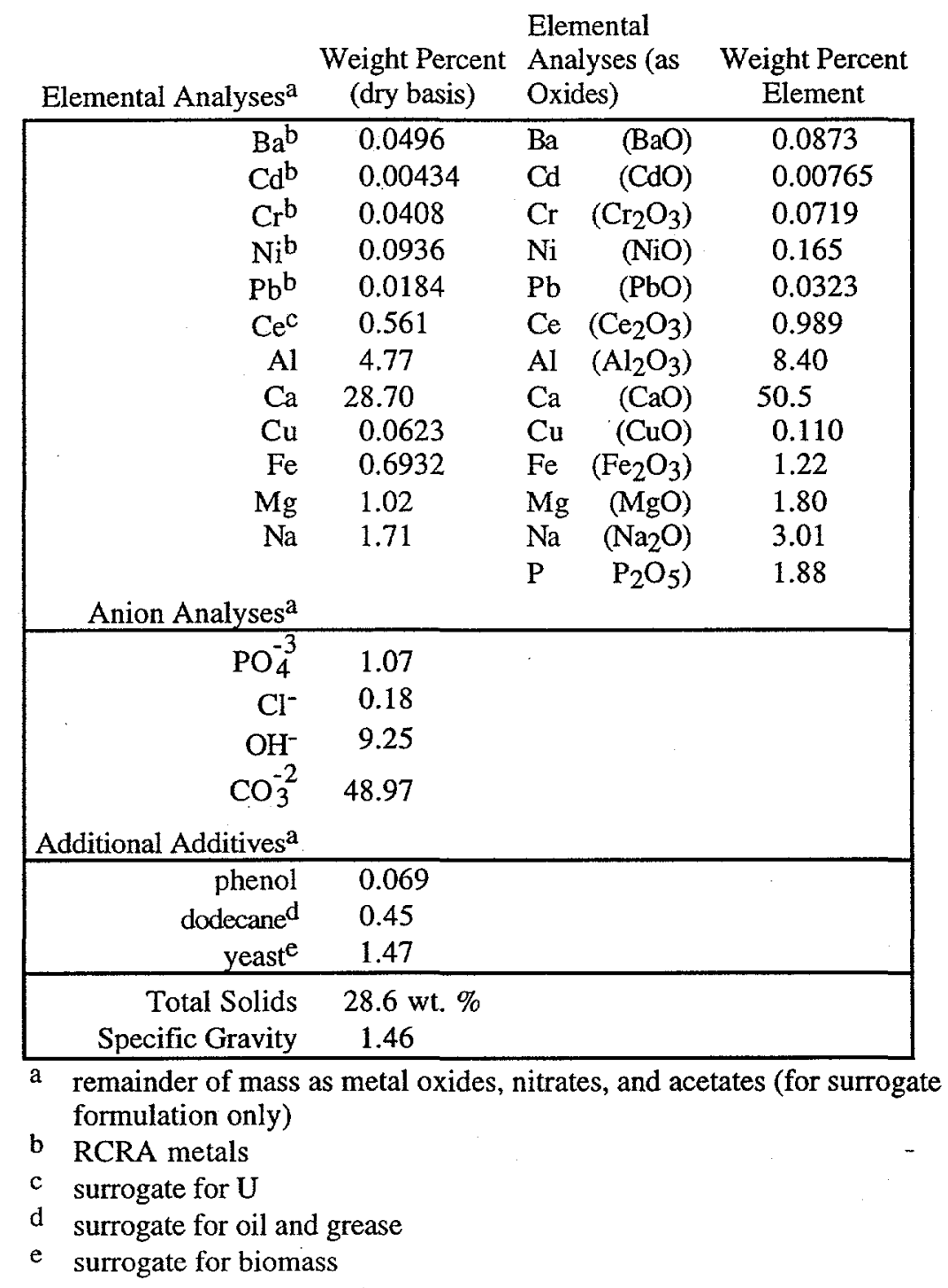


The final glass product for all three tests was targeted for 35 weight percent from the surrogate sludge (35 percent waste loading) and 65 weight percent from the glass additives ( 9 percent $\mathrm{Li}_{2} \mathrm{O}, 5$ percent $\mathrm{MgO}$, and 86 percent $\mathrm{SiO}_{2}$ ). This waste loading was targeted after crucible testing by ESED had shown problems with melting at waste loadings higher than 35 weight percent.

\section{Test Chronology}

The OR1-2 test was performed over the course of seven days. During the first day, a high drain tube temperature of $1800^{\circ} \mathrm{C}$ as measured by an optical pyrometer, was found. This high temperature was caused by the electrodes being positioned too close together, so they were moved apart. The total power to the electrodes for most of OR1-2 was about $60 \mathrm{~kW}$. For about 4 hours on the second day, the power was increased to $70 \mathrm{~kW}$, but was then lowered back to $60 \mathrm{~kW}$. Glass temperatures measured by a sacrificial dip tube thermocouple were well above $1500^{\circ} \mathrm{C}$ during this time. Unlike the TVS, there is no direct glass temperature measurement, so control of glass temperature is more difficult. It was determined, however, that a thermocouple placed in one of the electrodes gave a fairly good indication of the glass pool temperature. On the last day of this test, the glass temperature was lowered to about $1350^{\circ} \mathrm{C}$ by decreasing the total electrode power to $50 \mathrm{~kW}$. This glass temperature is more in line with that to be used on the TVS.

The OR1-3 test was completed in six days. The electrode temperature was $1350-1400^{\circ} \mathrm{C}$ and the total electrode power was about $50 \mathrm{~kW}$. On the second day of this test, one block of the refractory appeared hotter than the others, and therefore cooling air was blown onto it to allow the test to continue. The test was stopped after six days when the melter was automatically shut down due to a loss of nitrogen purge flow to the electrodes. The glass in the melter had to be chipped out before the OR1-4 test due to extensive crystallization during the slow cooldown at the end of OR1-3.

The final WETF test, OR1-4, was completed in nine days. The electrode temperature was $1350-1400^{\circ} \mathrm{C}$ and the electrode power was about $50 \mathrm{~kW}$ for this test as well.

\section{MELTER TEST RESULTS}

The melter feed rate for the three tests varied from 0.04 to $0.06 \mathrm{gpm}$, which gave a glass production rate of 8 to $10 \mathrm{lb} / \mathrm{hr}$. Glass pouring was done on a batch basis for 10 to 20 minutes per pour. Pours were made about every 8 hours. Usually the glass was poured into 8 inch graphite canisters. No major pouring problems were encountered.

\section{Melter Integrity}

The four molybdenum electrodes were inspected after the second test. The wear was found to be minimal on all four electrodes.

The main glass contact refractory installed in the EV-16 melter used for these tests was:Findlay Flux $\left(54.0 \% \mathrm{SiO}_{2}, 42.4 \% \mathrm{Al}_{2} \mathrm{O}_{3}\right)$. Findlay Flux was used as the main glass contact refractory in the TVS melter as well. In the EV-16 melter, the sidewalls were made of four Findlay Flux refractories that were 3 inches thick, 30 inches tall, and 21 inches wide.

Upon completion of the last test, the refractory wall located closest to the melter power supply was inspected. The refractory thicknesses are show schematically in Figure 1. This refractory wear is quite significant considering the short length of these tests (less than two months). On the fifth day of the first test (OR1-2), the refractory was probed on a non-electrode entering wall while the melter was hot and it was found that about 1.0 to 1.5 inches of the refractory had been lost. Therefore, it appears that a major portion of this wear occurred at the beginning of the first test, when the electrode temperature was high (up to 1658 ${ }^{\circ} \mathrm{C}$ ) and the glass temperature was greater than $1550^{\circ} \mathrm{C}$ for about 15 hours. Glass temperatures after this time were in the more reasonable range of $1350-1400^{\circ} \mathrm{C}$ and the electrode temperatures were less than $1400^{\circ} \mathrm{C}$ after the power to the melter was reduced. At a minimum, it is recommended that the TVS glass pool temperatures and electrode insertion distances are carefully monitored and controlled to extend the life of the glass contact refractories. If similar wear is observed with the TVS melter Findlay Flux refractory, 
then a higher grade, more expensive refractory such as high chrome Serv 30 should be used in a future TVS melter rebuild.

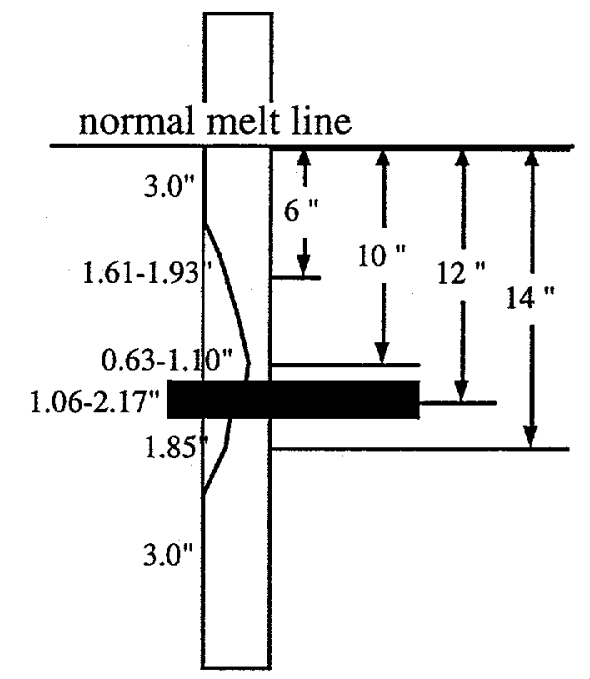

Figure 1. Melter Refractory Erosion

\section{Glass Collection Box Testing}

A prototype of the glass collection box to be used with the TVS at the ORR was tested. The open top box is eight cubic feet in size ( $2 \mathrm{ft}$. $\times 2 \mathrm{ft}$. $\times 2 \mathrm{ft}$.) and is made of $1 / 4$ inch thick carbon steel plate. It is separated into four quadrants by $1 / 8$ inch thick carbon steel plate. The boxes to be used at the ORR will be 304 stainless steel. Glass was poured at rates approximately at the nominal TVS pour rate of $150 \mathrm{lb} / \mathrm{hr}$ and also at $1500 \mathrm{lb} / \mathrm{hr}$ to test box integrity. The glass was deposited directly via approximately a 5 foot drop into the box.

At the $1500 \mathrm{lb} / \mathrm{hr}$ pour rate, the box exhibited significant heating; an area of approximately $10 \mathrm{inch}$ by 6 inch on all four faces of the quadrant being filled glowed red hot, with about 3 inch diameter area glowing yellow-white. In addition to the higher pour rate, the melter glass temperature was about $1400^{\circ} \mathrm{C}$ versus the anticipated 1200 to $1350^{\circ} \mathrm{C}$ range for the TVS melter.

In spite of the high pour rate and high glass temperature, no significant deformation of the box occurred. A small deformation of a $1 / 8$ inch thick divider involving its top 3 inches occurred when one of the quadrants was filled to overflowing. At the standard $150 \mathrm{lb} / \mathrm{hr}$ pour rate, the box did not show significant heating, and the glass flowed uniformly to fill the quadrant. The glass appeared to cool sufficiently where it contacted the box wall to form a self-containing barrier. This barrier allowed the glass to "overfill" the quadrant, rising perhaps an inch above the height of the dividers before it overflowed into the adjacent quadrant. Since the box was designed with a two-inch clearance between the top of the dividers and the top of the outer walls, one inch of safety margin exists, which should be sufficient. These results indicate that the design of the box is acceptable.

\section{Glass Characterization}

Table II shows the actual glass compositions of samples from each of the three tests versus the targeted glass composition. For all three tests, the actual amount of $\mathrm{Al}_{2} \mathrm{O}_{3}$ was found to be higher than the target amount. Higher $\mathrm{Al}_{2} \mathrm{O}_{3}$ increases the viscosity and the liquidus temperature for the glass. 
Table II. X.Ray Fluorescence Glass Analyses for WETF Tests Versus Target Composition

\begin{tabular}{|lcccccc|}
\hline $\begin{array}{l}\text { Oxide } \\
\text { (wt. \%) }\end{array}$ & $\begin{array}{c}\text { OR1-2 } \\
\text { Target }\end{array}$ & $\begin{array}{c}\text { OR1-2 } \\
\text { Sample }\end{array}$ & $\begin{array}{c}\text { OR1-3 } \\
\text { Target }\end{array}$ & $\begin{array}{c}\text { OR1-3 } \\
\text { Sample }\end{array}$ & $\begin{array}{c}\text { OR1-4 } \\
\text { Target }\end{array}$ & $\begin{array}{c}\text { OR1-4 } \\
\text { Sample }\end{array}$ \\
\hline $\mathrm{Al}_{2} \mathrm{O}_{3}$ & 5.71 & 8.08 & 5.46 & 7.07 & 5.71 & 6.19 \\
$\mathrm{BaO}$ & 0.036 & 0.039 & 0.035 & 0.037 & 0.036 & 0.037 \\
$\mathrm{CaO}$ & 25.1 & 23.4 & 24.0 & 24.2 & 25.1 & 24.5 \\
$\mathrm{CdO}$ & 0.003 & $\mathrm{NA}$ & 0.030 & $\mathrm{NA}$ & 0.003 & $\mathrm{NA}$ \\
$\mathrm{Ce} \mathrm{O}_{3}$ & 0.415 & 0.416 & 0.396 & 0.425 & 0.414 & 0.483 \\
$\mathrm{Cr}_{2} \mathrm{O}_{3}$ & 0.038 & 0.095 & 0.360 & 0.312 & 0.038 & 0.066 \\
$\mathrm{CuO}$ & 0.049 & 0.052 & 0.470 & 0.321 & 0.049 & 0.060 \\
$\mathrm{Fe}_{2} \mathrm{O}_{3}$ & 0.621 & 0.558 & 0.598 & 0.531 & 0.625 & 0.547 \\
$\mathrm{Li}_{2} \mathrm{O}$ & 5.85 & 5.92 & 5.85 & $\mathrm{NA}$ & 5.85 & $\mathrm{NA}$ \\
$\mathrm{MgO}$ & 4.18 & 4.20 & 4.14 & 4.22 & 4.18 & 4.49 \\
$\mathrm{Na}_{2} \mathrm{O}$ & 1.47 & 2.04 & 1.40 & 1.54 & 1.47 & 1.69 \\
$\mathrm{NiO}$ & 0.075 & 0.070 & 0.718 & 0.398 & 0.075 & 0.069 \\
$\mathrm{P}_{2} \mathrm{O}_{5}$ & 0.503 & 0.435 & 0.481 & 0.456 & 0.503 & 0.480 \\
$\mathrm{PbO}$ & 0.012 & 0.060 & 0.119 & 0.409 & 0.012 & 0.059 \\
$\mathrm{SiO}_{2}$ & 55.9 & 54.5 & 55.9 & 56.3 & 55.9 & 56.6 \\
\hline
\end{tabular}

NA $=$ not available

During the three tests, the final glass product was observed to have noticeable amounts of devitrification (crystallization). For the first test (OR1-2), lcss than 5\% crystaltization was observed. In the last canister poured in the sccond test (OR1-3), a 5.5 inch diameter section of gray crystals was found in the 8 inch diameter graphite canister. No devitrification was seen on the surface of the glass in this canister. This problem was seen to an even greater degree in the last test (ORI-4). The crystals were found mostly in the center of the containers. The erystals were analyzed and found to be mostly wollastonite with some Li-Al$\mathrm{Si}$ and $\mathrm{Mg}$-Al-Si crystals as well. In addition, the loss of nitrogen purge gas during the OR1-3 test caused the automatic shutdown of the melter and a premature end to this rest. An inspection of the glass in the melter after this shutdown indicated that substantial crystallization had occurred during the slow cooldown of the melter.

The crystallization was found to be the result of the slow glass cooldown in the canister. Crystallization occurred in both the graphite canisters and in the prototypic TVS boxes and therefore could be expected in the operation of the TVS with this glass composition. For waste glasses that are susceptible to crystallization, this finding showed the importance of flushing the TVS melter prior to shutdown with a glass composition that does not easily crystallize.

Crystallization had not been found during the small crucible studies that were done to develop this glass composition because the cooldown rate was much higher due to the substantially lower mass of the glass. The slow cooldown rate duting those tests held the glass in the crystal growth temperature range for sufficient time. Figure 2 shows how crystallization can occur through a typical Time-TemperatureTransformation (TTT) curve for glass. The shaded area is the zone in which crystallization will occur. If the temperature of the glass is above the liquidus (lowest temperature above the shaded area of crystal growth), then the material stays molten and no crystals are formed. If the glass is cooled quickly (cooldown curve 2) below the lower portion of the shaded crystal formation zone, then there is not sufficient energy or time for crystal growth. If however, the glass cooldown goes through the shaded crystal growth region (cooldown curve 1), then crystals will form. Longer time in this region results in more crystallization. Due to these findings, it is recommended that TTT studies be done on future waste glasses that sre to be processed by the TVS.

There are several possible solutions to the crystallization problem. The cooldown eurve may be shifted away from the area of crystal growth (as in cooldown curve 2) by cooling of the glass stream before it enters the containcr, making the container smaller so that the mass of the glass is less, or lowering the glass melter temperature. Another possible solution is to shift the area of erystal growth further to the 
right, thereby lowering the chances that the glass will be in this crystal growth region during cooldown. Shifting the crystal growth area can be done by changing the composition of the final glass product.

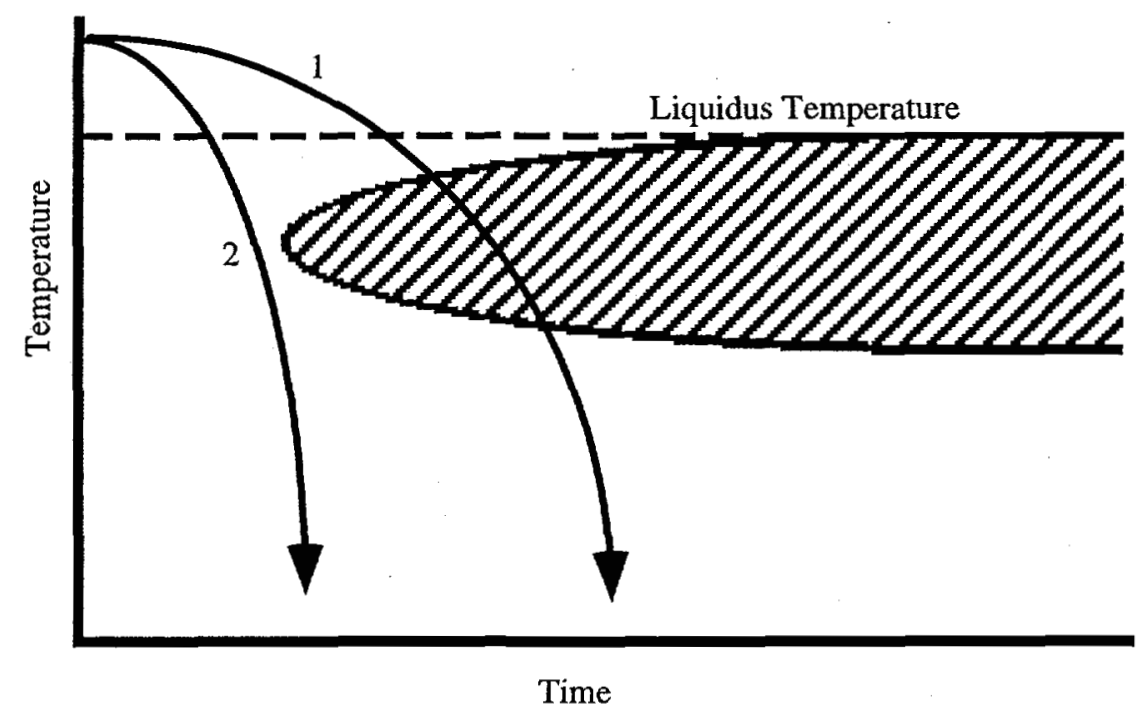

Figure 2. Typical Glass Time-Temperature-Transformation Curve

Subsequent crucible crystallization tests using $20 \%$ waste loading glass were successful in forming glass without crystals by this shifting of the "area of crystal growth". This lower waste loading moves the glass closer to the eutectic (low melting temperature point) on the $\mathrm{\Sigma R}_{2} \mathrm{O}-\mathrm{CaO}-\mathrm{SiO}_{2}$ ternary phase diagram (Figure 3, where $\mathrm{R}$ is $\mathrm{Na}, \mathrm{Li}$, and $\mathrm{K}$ ). This eutectic is located in the "known glass forming region" on Figure 3. This lower waste loading solution may be evaluated in future EV-16 tests with WETF surrogate.

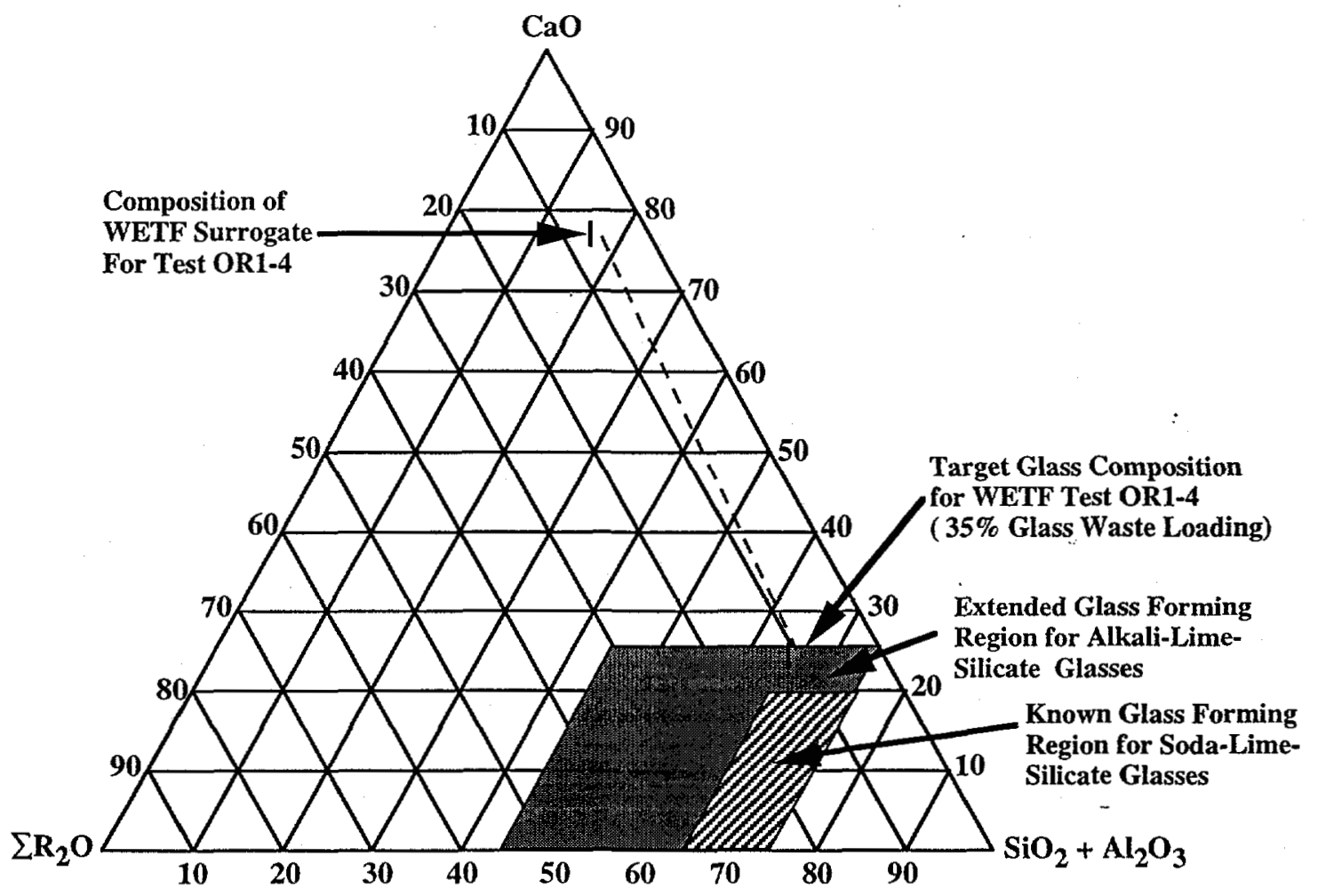

Figure 3. Ternary Phase Diagram for the System $\mathrm{\Sigma R}_{2} \mathrm{O}-\mathrm{CaO}-\mathrm{SiO}_{2}$ 


\section{TCLP Results}

Glass samples from each of the three tests were submitted to a contract laboratory (Triangle Labs in Durham, N.C.) for Toxicity Characteristic Leaching Procedure (TCLP) tests. The TCLP test entails soaking a granular glass sample in water for a specified time. The glass sample is then removed and the water analyzed for various elements to determine the levels of hazardous metals that have leached out of the glass. These levels, reported in $\mathrm{mg} / \mathrm{L}$, can then be compared to the EPA RCRA Universal Treatment Standards (UTS) for listed wastes. ${ }^{1,2,3}$ The RCRA metals included in the WETF surrogate were $\mathrm{Ba}, \mathrm{Cd}, \mathrm{Cr}$, $\mathrm{Pb}$, and $\mathrm{Ni}$.

The UTS limits and TCLP results for glasses from the three tests are shown in Table III. These results show that the WETF surrogate waste glasses met the UTS limits.

Table III. TCLP Results for WETF Surrogate Glasses

\begin{tabular}{|llccccc|}
\hline $\begin{array}{c}\text { Element } \\
(\mathrm{mg} / \mathrm{L})\end{array}$ & $\begin{array}{c}\text { RCRA UTS } \\
\text { Limits }\end{array}$ & $\begin{array}{c}\text { Test } \\
\text { OR1-2 }\end{array}$ & $\begin{array}{c}\text { Test } \\
\text { OR1-2 }\end{array}$ & $\begin{array}{c}\text { Test } \\
\text { OR1-3 }\end{array}$ & $\begin{array}{c}\text { Test } \\
\text { OR1-4 }\end{array}$ & $\begin{array}{c}\text { Test } \\
\text { OR1-4 }\end{array}$ \\
\hline $\mathrm{Ba}$ & 7.6 & 0.29 & 0.22 & 0.21 & 0.45 & 0.42 \\
$\mathrm{Cd}$ & 0.19 & 0.02 & 0.01 & 0.04 & 0.01 & 0.01 \\
$\mathrm{Cr}$ & 0.86 & 0.29 & 0.24 & 0.58 & 0.36 & 0.35 \\
$\mathrm{Ni}$ & 5.0 & 0.31 & 0.3 & 1.13 & 0.79 & 0.73 \\
$\mathrm{~Pb}$ & 0.37 & 0.06 & 0.06 & 0.08 & 0.13 & 0.09 \\
$\mathrm{Ce}$ & & 2.2 & 1.52 & 1.5 & 3.89 & 3.78 \\
$\mathrm{Al}$ & & 13.3 & 8.02 & 9.24 & 6.55 & 5.65 \\
$\mathrm{Ca}$ & & 93.5 & 89.3 & 88.0 & 223. & 221. \\
$\mathrm{Cu}$ & & 0.26 & 0.22 & 0.84 & 0.56 & 0.51 \\
$\mathrm{Fe}$ & & 2.39 & 2.57 & 2.14 & 5.82 & 5.28 \\
$\mathrm{~K}$ & & 1.41 & 0.78 & 0.8 & 1.4 & 1.35 \\
$\mathrm{Li}$ & & 16.4 & 13.8 & 15.7 & 40.4 & 43.8 \\
$\mathrm{Mg}$ & & 13 & 12.2 & 13.2 & 34.4 & 34.1 \\
$\mathrm{Na}$ & & 10.2 & 8.89 & 8.67 & 22 & 21.4 \\
$\mathrm{P}$ & & 0.64 & 0.54 & 0.7 & 1.05 & 1.05 \\
$\mathrm{Si}$ & & 60.4 & 49.9 & 46.3 & 73.4 & 74.7 \\
\hline
\end{tabular}

Glass samples were taken from tests OR1-3 and OR1-4 and analyzed by SRTC for glass redox. The $\mathrm{Fe}^{+2} / \mathrm{Fe}^{+3}$ ratio for these samples were 1.24 and 1.02 , respectively. Both of these values indicate very reduced glass. Reduced glass can potentially cause the reduction to and accumulation of elemental metals on the melter floor. Reduced glass also tends to have lower durability and is less likely to pass the TCLP. However, the glasses produced were acceptable in spite of being very reduced.

\section{OFFGAS AND PARTICULATE EMISSIONS}

The offgas from the melter was monitored using Environmental Protection Agency (EPA) Method 29 for multiple metals, a cascade impactor for particle size distribution and gas chromatography for permanent gases and low molecular weight organics. The sample point for Method 29 and the cascade impactor was the vent pipe immediately downstream from the melter. In contrast, the gas chromatography sample point was downstream of the offgas system.

\section{Gases}

The composition of the offgas from the EV-16 melter was measured by gas chromatography downstream of all of the offgas system scrubbers during the OR1-2 test. The compounds measured quantitatively were nitrogen, oxygen, carbon dioxide, carbon monoxide, and hydrogen. The carbon-containing materials in this test were the sludge and glassformer carbonates, phenol, and dodecane; no biomass (yeast) was present. The major offgas from the WETF sludge was carbon dioxide, which was generated from the decomposition of the carbonates. A mass balance showed that virtually all the carbonates were decomposed to carbon dioxide. The rate of evolution of carbon monoxide was about $0.2 \%$ of the carbon dioxide rate. Carbon monoxide 
could have been generated from the carbonates, phenol, or dodecane. Trace amounts of hydrogen were also detected. No $\mathrm{C}_{1}-\mathrm{C}_{8}$ hydrocarbons, which could result from decomposition of phenol or dodecane, were detected by gas chromatography.

\section{Particle Size}

The particle size distributions of the particulates in the melter offgas were determined using a cascade impactor. The results for the first (OR1-2) and second (OR1-3) tests are shown in Table IV and V, respectively. The cascade impactor was not used during the third test (OR1-4). The mean particle size (mass average) for the two tests ranged between 3 and about $12 \mu \mathrm{m}$. The observed particle size distributions are comparable to those of coal combustion and solid waste incinerators, which are in the range of 5-10 $\mu \mathrm{m} .{ }^{4,5}$

As shown in Tables IV and V, the mass average particle size for the second test (OR1-3) was lower than the average for the first test (OR1-2). This difference is attributed, at least in part, to the lower offgas flow rates that existed during the second test.

Table IV. Cascade Impactor Data For Test OR1-2

\begin{tabular}{|ccccc|}
\hline Stage & $\begin{array}{c}\mathrm{d} 50 \\
\text { (micron) }\end{array}$ & $\begin{array}{c}\text { Particulate } \\
\text { Mass / Filter } \\
(\mathrm{gram})\end{array}$ & $\begin{array}{c}\text { Fraction of } \\
\text { Total Mass } \\
(\%)\end{array}$ & $\begin{array}{c}\text { Cumulative \% } \\
<\mathrm{d} 50 \\
(\%)\end{array}$ \\
\hline Primary & 12.0 & 0.0484 & 54.63 & 45.37 \\
2 & 8.8 & 0.0057 & 6.43 & 38.94 \\
3 & 3.4 & 0.01 & 11.29 & 27.65 \\
4 & 1.6 & 0.0064 & 7.22 & 20.43 \\
5 & 0.86 & 0.0046 & 5.19 & 15.24 \\
6 & 0.42 & 0.0007 & 0.79 & 14.45 \\
7 & 0.18 & 0.0046 & 5.19 & 9.26 \\
Outlet & & 0.0082 & 9.26 & \\
\hline Total & & 0.0886 & 100. & \\
\hline
\end{tabular}

$\mathrm{T}_{\mathrm{S}}=440^{\circ} \mathrm{F}, \quad \mathrm{R}_{\mathrm{S}}=1.34 \mathrm{acfm}$

Table V. Cascade Impactor Data For Test OR1-3

\begin{tabular}{|lcccc|}
\hline Stage & $\begin{array}{c}\text { d50 } \\
\text { (micron) }\end{array}$ & $\begin{array}{c}\text { Particulate } \\
\text { Mass / Filter } \\
\text { (gram) }\end{array}$ & $\begin{array}{c}\text { Fraction of } \\
\text { Total Mass } \\
(\%)\end{array}$ & $\begin{array}{c}\text { Cumulative \% } \\
<\text { d }_{50} \\
(\%)\end{array}$ \\
\hline Primary & 12.0 & 0.0154 & 31.95 & 68.05 \\
2 & 9.0 & 0.0027 & 5.60 & 62.45 \\
3 & 3.4 & 0.0043 & 8.92 & 53.53 \\
4 & 1.7 & 0.0036 & 7.47 & 46.06 \\
5 & 0.88 & 0.0021 & 4.36 & 41.70 \\
6 & 0.43 & 0.0048 & 9.96 & 31.74 \\
7 & 0.2 & 0.0089 & 18.46 & 13.28 \\
Outlet & & 0.0064 & 13.28 & \\
\hline \multicolumn{1}{|c|}{ Total } & & 0.0482 & 100. & \\
\hline
\end{tabular}

$\mathrm{T}_{\mathrm{S}}=409^{\circ} \mathrm{F}, \quad \mathrm{R}_{\mathrm{S}}=1.26 \mathrm{acfm}$

The mass average particle size distribution assumed for the design of the TVS offgas system was $1 \mu \mathrm{m}$. Since the design particle size is much smaller than that measured during these tests, it is expected that the particulate scrubbing efficiencies in the TVS will be high. 


\section{Metals and Particulates}

The metals in the melter offgas were measured using EPA Method $29 .{ }^{6}$ The results obtained using Method 29 are shown in Tables VI and VII. This data was collected during the second test (OR1-3), which was conducted with the feed that contained ten times the expected amounts of the WETF surrogate RCRA metals $(\mathrm{Cr}, \mathrm{Cd}, \mathrm{Cu}, \mathrm{Pb}$, but not $\mathrm{Ni})$ and $\mathrm{Ce}(\mathrm{U}$ surrogate).

Table VI. EPA Method 29 Data For Test OR1-3

\begin{tabular}{|cccccc|}
\hline Metal & $\begin{array}{c}\text { Front End Mass } \\
(\mathrm{mg})\end{array}$ & $\begin{array}{c}\text { Back End Mass } \\
(\mathrm{mg})\end{array}$ & $\begin{array}{c}\text { Total Mass } \\
(\mathrm{mg})\end{array}$ & $\begin{array}{c}\text { Concentration } \\
(\mu \mathrm{g} / \mathrm{dscf})\end{array}$ & $\begin{array}{c}\text { Concentration } \\
(\mathrm{mg} / \mathrm{dscm})\end{array}$ \\
\hline $\mathrm{Cr}$ & 304 & 3.4 & 307 & 6.41 & 0.23 \\
$\mathrm{Cd}$ & 37628 & 6.9 & 37635 & 785.37 & 27.72 \\
$\mathrm{Cu}$ & 1590 & 0 & 1590 & 33.18 & 1.17 \\
$\mathrm{~Pb}$ & 9720 & 0.4 & 9720 & 202.85 & 7.16 \\
$\mathrm{Ni}$ & 1018 & 0.6 & 1019 & 21.26 & 0.75 \\
$\mathrm{Ce}$ & 167 & 0 & 167 & 3.48 & 0.12 \\
$\mathrm{Al}$ & 367 & 22.2 & 389 & 8.12 & 0.29 \\
$\mathrm{Fe}$ & 218 & 9.7 & 228 & 4.75 & 0.17 \\
$\mathrm{Na}$ & 10696 & 55.9 & 10752 & 224.37 & 7.92 \\
$\mathrm{P}$ & 344 & 0 & 344 & 7.18 & 0.25 \\
$\mathrm{Ca}$ & 17977 & 38.7 & 18016 & 375.95 & 13.27 \\
$\mathrm{Mg}$ & 1297 & 6 & 1303 & 27.19 & 0.96 \\
$\mathrm{Ba}$ & 34.6 & 0 & 35 & 0.72 & 0.03 \\
\hline $\mathrm{Total}$ & 81361 & 144 & 81504 & 1700.84 & 60.04 \\
\hline
\end{tabular}

Table VII. Metal Fraction Carryover For OR1-3

\begin{tabular}{|cc|}
\hline Metal & $\begin{array}{c}\text { Fraction } \\
\text { Carryover }\end{array}$ \\
\hline RCRA Metals and & \\
U Surrogate (Ce) & \\
$\mathrm{Cr}$ & $5.67 \times 10^{-4}$ \\
$\mathrm{Cd}$ & $6.54 \times 10^{-1}$ \\
$\mathrm{Cu}$ & $2.25 \times 10^{-3}$ \\
$\mathrm{~Pb}$ & $4.00 \times 10^{-2}$ \\
$\mathrm{Ni}$ & $8.21 \times 10^{-4}$ \\
$\mathrm{Ce}$ & $2.24 \times 10^{-4}$ \\
Non-RCRA & \\
Metals & \\
$\mathrm{Al}$ & $6.12 \times 10^{-5}$ \\
$\mathrm{Fe}$ & $2.46 \times 10^{-4}$ \\
$\mathrm{Na}$ & $4.91 \times 10^{-3}$ \\
$\mathrm{P}$ & $7.50 \times 10^{-4}$ \\
$\mathrm{Ca}$ & $4.72 \times 10^{-4}$ \\
$\mathrm{Mg}$ & $2.29 \times 10^{-4}$ \\
$\mathrm{Ba}$ & $5.16 \times 10^{-4}$ \\
\hline
\end{tabular}

Method 29 entails withdrawing a stack sample isokinetically and collecting particulate_matter in a sample probe and on a heated filter and collecting condensible gaseous matter in an impinger train containing aqueous acidic solutions. For classification of the collected matter as either particulate or gaseous, the sample train is divided at the filter. Metals collected on the filter or upstream of the filter are considered to be particulate matter, while metals collected downstream of the filter, including those collected in the aqueous acidic solutions, are considered to be gaseous. As can be seen from Table VI, the metal emissions 
in the vent pipe directly downstream of the melter are primarily in particulate form. On average, the metals are $99.8 \%$ particulate and $0.2 \%$ gaseous. This partition is not unexpected, since the offgas temperature at the sample point (about $200^{\circ} \mathrm{C}$ ) was much lower than the melt temperature (about $1350^{\circ} \mathrm{C}$ ).

The fraction of each metal fed to the melter that was carried-over into the vent pipe is shown in Table VII. The metals with oxide forms that have relatively high vapor pressures (e.g., $\mathrm{Cd}, \mathrm{Pb}$ ) exhibit the highest carry-over fractions. This finding suggests that volatilization enhanched the entrainment carry-over of the more volatile metals into the offgas.

Method 29 also provides a measurement of total particulates, similar to EPA Method 5. The concentration of total particulates in the offgas system just downstream of the melter was $179 \mathrm{mg} / \mathrm{dscm}$. This offgas particulate loading translates to a percent carryover (of feed total solids) of 0.079 weight percent.

\section{CONCLUSIONS}

The results of the three tests have shown that vitrification of ORR WETF sludge is attainable, although glass waste loadings may need to be lowered to prevent glass devitrification problems. Due to the devitrification observed, it is recommended that TTT studies be done on future waste glasses that are to be processed by the TVS so that steps can be taken to prevent this from happening during TVS operations. The glass produced from all three tests passed the TCLP criteria for UTS listed wastes. The testing of the prototypic glass collection box showed that the design was acceptable even up to pour rates of $1500 \mathrm{lb} / \mathrm{hr}$. The excessive refractory wear observed during the first test indicates that the main glass contact refractory material in the TVS (Findlay Flux) is susceptible to excessive wear if the glass temperature is too high. Crucible wear tests with Findlay Flux refractory are recommended to determine the upper temperature limit for any glass composition before it is used in the TVS. The vitrification of WETF sludge will probably not produce any significant amounts of hazardous gases. The particulate emissions measured show that the TVS offgas system scrubbing efficiency should be high.

\section{ACKNOWLEDGMENTS}

The success of these tests was due in large part to the efforts of many of the Clemson ESED personnel, including several graduate students. The preparation of the SCUREF contract by Connie Cicero is greatly appreciated. Participation in the testing by SRTC TVS personnel (Paul Burket, Erich Hansen, and John Whitehouse) was instrumental in the success of the tests. Finally, many thanks are given to Carol Jantzen (SRTC) for her work in developing the glass composition.

\section{REFERENCES}

1. Universal Treatment Standards, Code of Federal Regulations, 40 CFR 268.48.

2. Applicability of Treatment Standards - Treatment Standards for Hazardous Wastes, Code of Federal Regulations, 40 CFR 268.40.

3. Land Disposal Restrictions Phase II - Universal Treatment Standards , and Treatment Standards for Organic Toxicity Characteristic Wastes and Newly Listed Wastes, Federal Register, Vol. 59, No. 180, Sept. 19, 1994, p. 47982.

4. Hesketh, Howard E., Air Pollution Control, Ann Arbor Science Publishers, Inc., Ann Arbor, Michigan, 1979. p, 10.

5. Corbitt, Robert A., Standard Handbook of Environmental Engineering, McGraw-Hill, New York, 1990, p 8-168

6. Test Methods: Method 29: Determination of Metals Emissions from Stationary Sources, Code of Federal Regulations, 40 CFR 60, Appendix A. 